HELMINTHOLOGIA, 58, 2: 173 - 178, 2021

\title{
Multiple anthelmintic resistance at a goat farm in Slovakia
}

\author{
M. BABJÁK* , A. KÖNIGOVÁ, M. VÁRADY
}

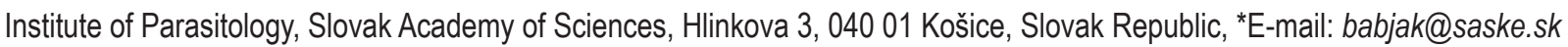

\section{Article info}

Received September 18, 2020

Accepted December 4, 2020

\section{Summary}

Cases of parasite resistance to the main classes of anthelmintics are increasingly reported from small ruminants at farms in Europe. We visited a goat farm in Slovakia in November 2019 with suspected parasite problems that reduced productivity and performed an in vivo faecal egg count reduction test (FECRT) and an in vitro larval development test (LDT) for all three main classes of anthelmintics. The lowest efficacy (60\%) detected by FECRT was for ivermectin (IVM). Benzimidazole (BZ) efficacy ranged between 80.3 and $86.5 \%$, and levamisole (LEV) efficacy was $94 \%$. The results from the in vivo FECRT test were confirmed by the in vitro LDT. Minimum inhibitory concentration (MIC) $173.6 \mathrm{ng} / \mathrm{ml}$ for IVM several times exceeded the recommended threshold of $21.6 \mathrm{ng} / \mathrm{ml}$. Mean $\mathrm{LD}_{50}$ for $\mathrm{BZ}$ was equal to the threshold concentration, but the other threshold criteria indicated a low level of resistance in the population. The LDT did not indicate the presence of resistance only for LEV. The MIC $1.0 \mu \mathrm{g} / \mathrm{ml}$ for LEV was evaluated as susceptible with respect to species composition. Teladorsagia was the dominant genus after treatment with BZ, IVM, and LEV. Haemonchus contortus was identified after treatment with BZ and LEV.

Keywords: Small ruminants; anthelmintic resistance; ivermectin; benzimidazole; Teladorsagia spp.; Haemonchus contortus

\section{Introduction}

Anthelmintic resistance (AR) to the main classes of anthelmintics is rapidly increasing in small ruminants at farms throughout the world. Multidrug resistance is common on sheep farms in humid tropical areas of Central and South America where was reported lack of in vivo efficacy for recommended dosages of ivermectin, albendazole and levamisole (Herrera-Manzanilla et al., 2017; Chaparro et al., 2017) or reduced effectiveness of macrocyclic lactones and benzimidazoles (Santiago-Figureoa et al., 2019). In Europe, multidrug resistance has been detected in Haemonchus contortus in The Netherlands (Van den Brom et al., 2013) and France (Cazajous et al., 2018) and in Teladorsagia circumcincta in Ireland (Keegan et al., 2015). Information has been lacking in recent decades about the prevalence of $A R$ in goat herds, because most surveys have focused on sheep. A comparison of parasitism with gastrointestinal nematodes (GINs) found that only $20-25 \%$ of studies included goats (Hoste et al., 2010). Cases of AR at goat farms in Europe have been reported from France (Paraud et al., 2009), Italy (Cringoli et al., 2007; Zanzani et al., 2014), Demark (Holm et al., 2014), and Poland (Mickiewicz et al., 2017; 2019). Despite these reports, more surveys need to be conducted at goat farms. The owner of the farm in our study suspected poor efficacy of benzimidazoles (BZs) due to low weight gains and high morbidity of yearlings. The main goal of this study was thus to test the presence of $\mathrm{BZ}$ resistance on this farm. Two additional an-

\footnotetext{
* - corresponding author
} 
thelmintics, ivermectin (IVM) and levamisole (LEV) were included to test their efficacies. Another objective was to morphologically identify species of nematodes from larval cultures before and after treatment.

\section{Materials and Methods}

\section{Study design}

The farm was situated in the lowlands of the southeastern part of Slovakia. The herd consisted of three adult males, 86 adult females, and 31 kids of White and Brown short-haired goats. The animals were grazed from March to November on a 28-ha pasture. Ten sheep shared the pasture with the goats. We collected faecal samples from 50 goats with similar ages selected from the herd in November 2019. The number of eggs per gram (EPG) of faeces was determined by flotation using a sugar solution with specific gravity 1.28 according modified McMaster technique with a sensitivity of 50 EPG (Coles et al., 1992). Twenty-one goats with EPGs $>500$ were subsequently split into three groups of seven animals. On day 0 , group 1 was treated with $5 \mathrm{mg} / \mathrm{kg}$ body weight (bw) of albendazole, the recommended dose for small ruminants but specific for sheep (Albendavet, DIVASA-FARMAVIC S.A., Barcelona, Spain), group 2 was treated with IVM at a dose of $200 \mu \mathrm{g} / \mathrm{kg}$ bw (Ivomec, MERIAL, Lyon, France), and group 3 was treated with LEV at a dose of $5 \mathrm{mg} / \mathrm{kg}$ bw (Ripercol Drench, Elanco, Greenfield, USA). Eggs were counted 0 and $10 \mathrm{~d}$ after treatment.

\section{Faecal egg count reduction test (FECRT)}

The FECRT was conducted following the recommendations of the World Association for the Advancement of Veterinary Parasitology (Coles et al., 1992, 2006). Percent egg reduction (\%FECR) was calculated using two methods: \%FECR $=(1 / n) \sum\left(100 \times\left(1-\left[T_{i 2} / T_{i 1}\right]\right)\right.$, where $T_{i 1}$ and $T_{i 2}$ are pre- and post-treatment EPGs, respectively, in host $i$ from a total of $n$ hosts (Cabaret \& Berrag, 2004), and \%FECR $=100 \times\left(1-\left[T_{2} / T_{1}\right]\right)$, where $T_{1}$ and $T_{2}$ are the arithmetic means of the treated group before and after treatment, respectively, with no control group (Kochapakdee et al., 1995). The parasite population was considered resistant if \%FECR was $<95 \%$ (McKenna, 1990).

\section{Larval development test (LDT)}

The in vitro LDT was used as described by Hubert and Kerboeuf (1992), with modifications as described by Várady et al. (1996). The test for each group was performed with two replicates. Helminth eggs recovered from the faeces were incubated for $7 \mathrm{~d}$ in 96-well microtitre plates containing culture medium (yeast extract with Earle's Balanced Salt Solution and a physiological salt solution) in aqueous solutions at various concentrations of thiabendazole (TBZ) $(0.0006-1.28 \mu \mathrm{g} / \mathrm{ml})$, IVM aglycone $(0.084-173.6 \mathrm{ng} /$ $\mathrm{ml})$, and LEV $(0.020-32 \mu \mathrm{g} / \mathrm{ml})$. The test was performed on two occasions before treatment. The concentrations of TBZ, needed to inhibit development to third-stage larvae $\left(\mathrm{L}_{3}\right)$ by $50 \%\left(\mathrm{LD}_{50}\right)$ and $99 \%\left(\mathrm{LD}_{99}\right)$ were determined using a logistic regression model (Dobson et al., 1987). We determined whether a parasite population was resistant to $\mathrm{BZ}$ based on threshold parameters such as $L_{50}(0.02 \mu \mathrm{g} / \mathrm{ml})$, the minimum concentration required to completely inhibit the development of larvae to the $\mathrm{L}_{3}$ stage (MIC), and $\mathrm{LD}_{99}(0.03 \mu \mathrm{g} / \mathrm{ml})$ (Coles et al., 2006; Várady et al., 2006). IVM resistance have been confirmed using the MIC threshold of 21.6 ng/ml IVM aglycone by Dolinská et al. (2014). LEV resistance was assessed on the basis of discriminating doses of $0.5 \mu \mathrm{g} / \mathrm{ml}$ established by Coles et al., 2006, $1.0 \mu \mathrm{g} / \mathrm{ml}$ (Coles et al., 1988) and $2.5 \mu \mathrm{g} / \mathrm{ml}$ (Taylor, 1989). $\mathrm{L}_{3}$ larvae of genera from the nematode family Trichostrongylidae were harvested using the Baermann technique, and 100 randomly selected $L_{3}$ were identified before treatment. One hundred $\mathrm{L}_{3}$ larvae were identified from each treatment group $10 \mathrm{~d}$ after treatment as described by Van Wyk \& Mayhew (2013).

\section{Ethical Approval and/or Informed Consent}

All procedures performed in this study were in accordance with the ethical standards of the Ethics Committee on 20-April-2015, meets the requirements of the Ethics Committee of the Institute of Parasitology of the Slovak Academy of Sciences in accordance with the national legislation in Slovakia - Animal Welfare Act No. 23/2009 and was approved on 1-January-2016.

\section{Results}

\section{FECRT}

The results of the FECRT are presented in Table 1. EPGs of strongyle-type eggs at day 0 ranged from 550 to 4850 . Low numbers of Nematodirus and Trichuris eggs were also detected. Only strongylid eggs were detected $10 \mathrm{~d}$ after treatment in all groups. The FECRT results indicated close agreement between both methods of calculation. The lowest efficacy was recorded in the IVM group, with reductions of 59 and $60.4 \%$ using the Cabaret \& Berrag (2004) and Kochapakdee et al. (1995) methods, respectively. The

Table 1. Results of the in vivo FECRT: percent reduction 10 days after treatment.

\begin{tabular}{cccc}
\hline Method of calculation & \multicolumn{3}{c}{ FECR (\%) } \\
\cline { 2 - 4 } & BZ group & IVM group & LEV group \\
\hline Cabaret and Berrag (2004) & 80.3 & 59.0 & 94.2 \\
Kochapakdee (1995) & 86.5 & 60.4 & 94.0 \\
\hline
\end{tabular}

FECRT, faecal egg count reduction test; BZ, benzimidazole; IVM, ivermectin; LEV, levamisole 
Table 2. Values of $L_{50}$ and MIC from the LDT for each group of goats.

\begin{tabular}{ccc}
\hline $\mathrm{LD}_{50} \pm \mathrm{SD}$ & $\mathrm{MIC}$ & $\mathrm{MIC}$ \\
$\mathrm{BZ}$ group & IVM group & LEV group \\
$(\mu \mathrm{g} / \mathrm{ml})$ & $(\mathrm{ng} / \mathrm{ml})$ & $(\mu \mathrm{g} / \mathrm{ml})$ \\
$0.020 \pm 0.0007$ & 173.6 & 1.0 \\
\hline LDT, larval development test; SD, standard deviation; $\mathrm{LD}_{50}$, concentration that inhibits development to the $\mathrm{L}_{3}$ \\
stage by $50 \% ;$ MIC, minimum inhibitory concentration; $\mathrm{BZ}$, benzimidazole; IVM, ivermectin; LEV, levamisole
\end{tabular}

BZ group had efficacies of 80.3 and $86.5 \%$, and the LEV group had efficacies of 94.0 and $94.2 \%$, using the Cabaret \& Berrag (2004) and Kochapakdee et al. (1995) methods, respectively.

\section{LDT}

The in vitro LDT was performed to confirm the results of the in vivo FECRT. Mean $\mathrm{LD}_{50}$ for all three groups of goats is presented in Table 2. Mean $\mathrm{LD}_{50}$ was $0.02 \mu \mathrm{g} / \mathrm{ml}$ TBZ, identical to the threshold concentration. The high minimum inhibitory concentration (MIC) values in both assays $\left(1.28 \mu \mathrm{g} / \mathrm{ml}\right.$ TBZ) and $\mathrm{LD}_{99}(0.104 \pm 0.098$ $\mu \mathrm{g} / \mathrm{ml} \mathrm{TBZ}$ ), however, indicated a low (approximately $10-15 \%$ ) level of BZ resistance in the population. MIC values for IVM aglycone $(173.6 \mathrm{ng} / \mathrm{ml})$ were several times higher than the discriminating dose of $21.6 \mathrm{ng} / \mathrm{ml}$ indicating a high level of IVM resistance at farm. The MIC $1.0 \mu \mathrm{g} / \mathrm{ml}$ for LEV group was in agreement with the results of FECRT and parasite population was considered as susceptible.

Morphological differentiation of $L_{3}$ larvae

Morphological identification of $\mathrm{L}_{3}$ larvae before treatment indicated the presence of $\mathrm{H}$. contortus, Teladorsagia, Trichostrongylus, and Oesophagostomum/Chabertia ovina (Table 3). Teladorsagia was the only genus identified in the IVM group $10 \mathrm{~d}$ after treatment. Teladorsagia was also the dominant genus in the LEV and BZ groups. H. contortus was also identified in both groups.

\section{Discussion}

We confirmed the presence of a multidrug-resistant strain of Teladorsagia and a BZ-resistant strain of $\mathrm{H}$. contortus. The efficacy of the FECRT was lowest (approximately $60 \%$ ) in the IVM group, which was also confirmed by LDT, despite the suspicion of the ineffectiveness of BZs. This low efficacy was probably the consequence of frequent use and incorrect dosing for many years and can be expected on most goat farms where similar approaches of farm management have been applied. Nationwide data on the prevalence of IVM resistance in goat herds in Slovakia, however, is still lacking. IVM has been used for decades to prevent and treat ectoparasites and may lead to selection pressure on gastrointestinal parasites that can in turn lead to the development of AR at farms (Cazajous et al., 2018).

The first national survey of goat farms, which focused only on BZs, was not carried out until $2014-2016$ and detected AR on 30 farms (Babják et al., 2018), long after multidrug-resistant strains were detected in goats imported from New Zealand (Várady et al., 1993). A similar national survey would also be desirable for macrocyclic lactones (MLs) due to the critical situation of the prevalence of BZ resistance. Our results for the IVM group support this statement.

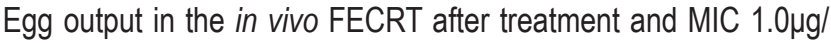
$\mathrm{ml}$ from LDT indicated the presence of a sensitive GIN population, perhaps because LEV-based products have not been available on the local market for more than two decades and have therefore not been used. The presence of almost $10 \% \mathrm{~L}_{3}$ larvae of $H$. contortus in the larval cultures for the LEV group after therapy however, indicates the continued monitoring of efficacy. Discriminating dose of $0.5 \mu \mathrm{g} / \mathrm{ml}$ according to Coles et al. (2006) was exceeded, but due to the presence of $H$. contortus larvae after therapy as well as in the LDT at concentration of $0.5 \mu \mathrm{g} / \mathrm{ml}$, a threshold used by Taylor et al. (1989) $2.5 \mu \mathrm{g} / \mathrm{ml}$ has been applied. The population would be assessed as susceptible even if we used the threshold $1.0 \mathrm{\mu g} /$ $\mathrm{ml}$ established by Coles et al. (1988) for Trichostrongylus colubriformis. Despite these differences in thresholds for each species, the value of $1.0 \mu \mathrm{g} / \mathrm{ml}$ can be considered as a borderline between susceptible and resistant population, and it is necessary to control

Table 3. Results of the morphological identification of $\mathrm{L}_{3}$ larvae before and after treatment.

\begin{tabular}{cccccc}
\hline Before treatment (\%) & \multicolumn{5}{c}{ After treatment (\%) } \\
\hline Nematode & $\%$ & Nematode & BZ group & IVM group & LEV group \\
Teladorsagia & 45 & Teladorsagia & 79 & 100 & 91 \\
Haemonchus contortus & 17 & Haemonchus contortus & 21 & - & 9 \\
Oesophagostomum/Chabertia ovina & 19 & Oesophagostomum/Chabertia ovina & - & - & - \\
Trichostrongylus & 19 & Trichostrongylus & - & - & - \\
\hline
\end{tabular}

$\mathrm{BZ}$, benzimidazole; IVM, ivermectin; LEV, levamisole 
the effectiveness of LEV in the future and use the correct dosing of drug in therapy.

An effective anthelmintic strategy needs the administration of the correct dose of drug tailored to the metabolic and physiological characteristics of each host species. Underdosing is one of the most important factors responsible for accelerating the development of AR (Torres-Acosta \& Hoste, 2008). A survey of goat farms conducted in northern Italy found that recommended doses for sheep were applied at six of eight farms tested, and only three farms had an adequate efficacy of ML (Lambertz et al., 2019). Eprinomectin (EPM) is currently the only anthelmintic with no milk-withdrawal period authorized for goats. The development of an optimal pour-on dose of EPM for dairy goats is currently being discussed due to differences in reduction between lactating and dry goats and to strong individual variability with the pour-on formulation (Rostang et al., 2020). The importance of correct dosing was demonstrated by a case in Poland, where EPM resistance developed after two years of use (Mickiewicz et al., 2019). Murri et al. (2014) conducted a survey of 43 goat farms in the canton of Berne, Switzerland, where 39 farms had faecal egg reductions $<90 \%$ after the application of the recommended dose of EPM (1 mg/kg bw). More clinical studies are needed to confirm the recommended dose of EPM in goats, especially in countries where similar studies have not been yet performed. A reduced efficacy of EPM can be also expected at Slovak farms, because its mechanism of action is the same as for other MLs.

Compared to sheep, goats require a different approach in drug dosing due to higher metabolic rate. Most of anthelmintics commonly applied on farms still do not have a licensed dose for use in goats (Várady et al., 2011). Differences in drug bioavailability between sheep and goats were demonstrated by Sharma et al. (2014), where treatment with the same doses of LEV and fenbendazole reduced faecal egg counts by $100 \%$ in sheep but only by 82.60 and $78.87 \%$, respectively, in goats. Using double doses of anthelmintics would be appropriate in goats from the point view of farm management and the prevention of the development and spread of AR. Cringoli et al. (2004) observed significant differences in percentage egg reduction between single $(0.5 \mathrm{mg} / \mathrm{kg} \mathrm{bw})$ and double dose (1 mg/kg bw) of EPM in naturally infected goats. The survey of 30 goat farms in Slovakia by Babják et al. (2018), however, found that the use of a double dose in the FECRT could underestimate the presence of resistant strains. The dose recommended for sheep for the diagnosis of AR using the in vivo FECRT would therefore be more suitable, which could also indicate the low level of AR at goat farms and for this reason was this approach also applied in the current study.

Faecal examination before treatment and subsequent selective therapy is another approach that is still not applied in many countries. Valcárcel et al. (2015) applied three systems of targeted selective treatment (egg output, clinical signs, and criteria of live weight) for two consecutive years to reduce the frequency of treatment from 37.95 to $100 \%$ without affecting health or production.
The approaches of targeted selective therapies are costly but can prevent the development of resistance, which can cause greater production and financial losses. The application of anthelmintics at many farms is often used as the first solution without prior clinical or laboratory diagnosis. Factors such as underdosing, poor estimation of weight, and ignoring differences between sheep and goats were also reported by Mickiewicz et al. (2017) for the first case of BZ resistance in goats in Poland. BZs and MLs in our study were frequently applied more than twice a year. The owner also did not quarantine newly purchased animals, which could serve as sources of resistant parasites, as has been described in several studies (Várady et al., 1993; Himonas \& Papadopoulos, 1994; Requejo-Fernandez et al., 1997). All new animals in our study were from Slovakia, so we can expect the presence of multidrug-resistant parasites on several other farms if the animals were sources of AR parasites. This case is an example of how the most common faults in farm management can lead to the development of resistance to multiple anthelmintics.

\section{Conflict of Interest}

Authors state no conflict of interest.

\section{Acknowledgements}

This study was supported by funds from the Scientific Grant Agency VEGA 2/0099/19 and Slovak Research and Development Agency APVV-18-0131. The authors thank S. Spišáková and M. Krčmárik for their technical assistance.

\section{References}

Babják, M., Königová, A., URda Dolinská, M., Vadlejch, J., Várady, M. (2018):Anthelmintic resistance in goat herds-in vivo versus in vitro detection methods. Vet. Parasitol., 254: 10 - 14. DOI: 10.1016/j.vetpar.2018.02.036

CabARet, J., BerRag, B. (2004): Faecal egg count reduction test for assessing anthelmintic efficacy: average versus individually based estimations. Vet. Parasitol., 121(1-2): 105 - 113. DOI: 10.1016/j. vetpar.2004.01.020

Cazajous, T., Prevot, F., Kerbiriou, A., Mllhes, M., Grisez, C., Tropee, A., Godart, C., Aragon, A., Jacquiet, P. (2018): Multiple-resistance to ivermectin and bezimidazole of a Haemonchus contortus population in a sheep flock from mainland France, first report. Vet. Parasitol. Reg. Stud. Reports., 14: 103 - 105. DOI: 10.1016/j. vprsr.2018.09.005

Coles, G.C., Tritschler, J.P. II, Giordano, D.J., Laste, N.J., SCHMIDT, A.L. (1988): Larval development test for detection of anthelmintic resistant nematodes. Res. Vet. Sci., 45(1): 50 - 53. DOl:.org/10.1016/S0034-5288(18)30893-2

Coles, G.C., Bauer, C., Borgsteede, F.H.M., Geerts, S., Klei, T.R., TAYLoR, M.A., Waller, P.J. (1992): World Association for the Ad- 
vancement of Veterinary Parasitology (W.A.A.V.P.) methods for the detection of anthelmintic resistance in nematodes of veterinary importance. Vet. Parasitol., 44(1-2): 35 - 44. DOI: 10.1016/03044017(92)90141-U

Coles, G.C., Jackson, F., Pomroy, W.E., Prichard, R.K., Von Samson-Himmelstjerna, G., Silvestre, A., Taylor, M.A., Vercruysse, J. (2006): The detection of anthelmintic resistance in nematodes of veterinary importance. Vet. Parasitol., 136(3-4): 167 - 185. DOI: 10.1016/j.vetpar.2005.11.019

Cringoli, G., Rinaldi, L., Veneziano,V., Capelli,G., Rubino, R.(2004). Effectiveness of eprinomectin pour-on against gastrointestinal nematodes of naturally infected goats. Small Rumin. Res., 55 (13): 209 - 213. DOI:.org/10.1016/j.smallrumres.2004.02.008

Cringoli, G., Veneziano, V., Rinaldi, L., Sauvé, C., Rubino, R., Fedele, V., Cabaret J. (2007): Resistance of trichostrongyles to benzimidazoles in Italy: A first report in a goat farm with multiple and repeated introductions. Parasitol. Res., 101(3): 577 - 581. DOI: 10.1007/s00436-007-0518-7

Dobson, R.J., Griffiths, D.A., Donald, A.D.,Waller, P.J. (1987): A genetic model describing the evolution of levamisole resistance in Trichostrongylus colubriformis, a nematode parasite of sheep. J. Math. Appl. Med. Biol., 4 (4): 279 - 293. DOI: 10.1093/ imammb/4.4.279

Dolinská, M., IVANIŠINOVÁ, O., KönIGOVÁ, A., Várady, M. (2014): Anthelmintic resistance in sheep gastrointestinal nematodes in Slovakia detected by in vitro methods. BMC Vet. Res., 10: 233. DOI: 10.1186/s12917-014-0233-4

Herrera-Manzanilla, F.A., Ojeda-Robertos, N.F., González-Garduño, R., Cámara-Sarmiento, R., Torres-Acosta, J.F.J. (2017): Gastrointestinal nematode populations with multiple anthelmintic resistance in sheep farms from the hot humid tropics of Mexico. Vet. Parasitol. Reg. Stud. Reports., 9: 29 - 33. DOI: 10.1016/j. vprsr.2017.04.007

Himonas, C., Papadopoulos, E. (2004): Anthelmintic resistance in imported sheep. Vet. Rec., 134(17): 456. DOI: 10.1136/vr.134.17.456 Holm, S.A., Sorensen, C.R.L., Thamsborg, S.M., Enemark, H.L. (2014): Gastrointestinal nematodes and anthelmintic resistance in Danish goat herds. Parasite, 21: 37. DOI: 10.1051/parasite/2014038

Hoste, H., Sotiraki, S., Landau, S.Y., Jackson, F., Beveridge, I. (2010): Goat-Nematode interactions: think differently. Trends Parasitol., 26(8): 376 - 381. DOI:10.1016/j.pt.2010.04.007

HUBERT, J., KERBOEUf,D . (1992): A microlarval development assay for the detection of anthelmintic resistance in sheep nematodes. Vet. Rec., 130(20): 442 - 446. DOI: 10.1136/vr.130.20.442

Chaparro, J.J., Villar, D., Zapata, J.D., López, S., Howell, S.B., LóPEZ, A., StoREY, B.E. (2017): Multi - drug resistant Haemonchus contortus in a sheep flock in Antioquia, Colombia. Vet. Parasitol. Reg. Stud. Reports., 10: 29 -34. DOI: 10.1016/j.vprsr.2017.07.005 Keegan, J.D., Keane, O.M., Farrell, L., Byrne, W., De Waal, T., Good, B. (2015): Characterisation of ivermectin and multidrug resistance in two field isolates of Teladorsagia circumcincta from
Irish sheep flocks. Vet. Parasitol. Reg. Stud. Reports., 1-2: 3 - 9. DOI: 10.1016/j.vprsr.2016.03.005

Kochapakdee, S., Pandey, V.S., Pralomkarm, W., Choldumrongkul, S., Ngampongsal, W.N.,LAWPETCHARA, A.(1995): Anthelmintic resistance in goat in southern Thailand. Vet. Rec. 137(5): $124-125$. DOI: 10.1136/vr.137.5.124

Lambertz, C., Poulopoulou, I., Wuthijaree, K., Gauly, M. (2019): Anthelmintic efficacy against gastrointestinal nematodes in goats raised under mountain farming conditions in northern Italy. BMC. Vet. Res.,15:216. DOI: 10.1186/s12917-019-1968-8

McKenNA, P.B. (1990): The detection of anthelmintic resistance by the faecal egg count reduction test: an examination of some of the factors affecting performance and interpretation. N. Z. Vet. J., 38(4): 142 - 147. DOI: 10.1080/00480169.1990.35640

Mickiewicz, M., CZopowicz, M., GóRskI, P., KabA, J. (2017): The first reported case of resistance of gastrointestinal nematodes to benzimidazole anthelmintic in goats in Poland. Ann. Parasitol., 63(4): 317 - 322. DOI: $10.17420 / a p 6304.118$

Mickiewicz, M., CZopowicz, M., Moroz, A., Szaluś-Jordanow, O., Górski, P., Várady, M., Königová, A., Spinu, M., Lefkaditis, M., Kaba, J. (2019): Development of resistance to eprinomectin in gastrointestinal nematodes in a goat herd with pre-existing resistance to benzimidazoles. Pol. J. Vet. Sci., 22(4): 753 - 760. DOI: 10.24425/ pjvs.2019.131404

Murri, S., Knubben-Schweizer, G., Torgerson, P., Hertzberg, H. (2014): Frequency of eprinomectin resistance in gastrointestinal nematodes of goats in canton Berne, Switzerland. Vet. Parasitol., 203(1-2): 114 - 119. DOI: 10.1016/j.vetpar.2014.02.052

Paraud, C., Kulo, A., Pors, I., Chartier, C. (2009): Resistance of goat nematodes to multiple anthelmintics on a farm in France. Vet. Rec., 164 (18): 563 - 564. DOI: 10.1136/vr.164.18.563

Requejo-Fernández, J. A., Martinez, A., Meana, A., Rojo-Vázquez, F. A., Osoro, K., ORTEGA-MorA, L. M . (1997): Anthelmintic resistance in nematode parasites from goats in Spain. Vet. Parasitol., 73(1-2): 83 - 88. DOI: 10.1016/s0304-4017(97)00043-5

Rostang, A., Devos,J., Chartier,C. (2020): Review of the Eprinomectin effective doses required for dairy goats: Where do we go from here? Vet. Parasitol., 277: 108992. DOI: 10.1016/j. vetpar.2019.108992

Santiago-Figueroa, I., Lara-Bueno, A., González-Garduño, R., López-Arellano, M.E., de la Rosa-Arana, J.L., Maldonado-Simán, E.D.J. (2019): Anthelmintic resistance in hair sheep farms in a sub-humid tropical climate, in the Huasteca Potosina, Mexico. Vet. Parasitol. Reg. Stud. Reports., 17: 100292. DOI: 10.1016/j. vprsr.2019.100292

ShaRMA, D., VatSYA, S., KumaR, R.R.(2016): Impact of treatment of gastrointestinal nemathelminths on body weight of sheep and goats. J. Parasit. Dis., 40(3): 801 - 804. DOI: 10.1007/s12639014-0581-9

TAYLOR, M.A., HUNt, K.R. (1989): Anthelmintic drug resistance in the UK. Vet.Rec., 125(7): 143 - 147. DOI: 10.1136/vr.125.7.143

TORRES-ACOSTA, J.F.J., Hoste, H. (2008): Alternative or improved 
methods to limit gastro-intestinal parasitism in grazing sheep and goats. Small Rum. Res., 77(2): 159 - 173. DOI: 10.1016/j.smallrumres.2008.03.009

Van den Brom, R., Moll, L., Borgsteede, F.H.M., Van Doorn, D.C.K., Lievaart-Peterson, K., Drecksen, D.P., Vellema, P. (2015): Multiple anthelmintic resistance of Haemonchus contortus, including a case of moxidectin resistance, in a Dutch sheep flock. Vet. Rec., 173(22): 552. DOI: 10.1136/vr.101700

Valcárcel,F., Aguilar,A., SÁnchez,M. (2015): Field evaluation of targeted selective treatments to control subclinical gastrointestinal nematode infections on small ruminant farms. Vet. Parasitol., 211(1-2): 71 - 79. DOI: 10.1016/j.vetpar.2015.04.014

VAN WYK, J.A., MAYHEW, E. (2013): Morphological identification of parasitic nematode infective larvae of small ruminants and cattle: a practical lab guide. Onderstepoort J. Vet. Res., 80(1): 539. DOI:10.4102/ojvr. v80i1.539
VÁrady, M., PrasličKa, J., Čorba, J.,Vesely, L.(1993): Multiple anthelmintic resistance of nematodes in imported goats. Vet.Rec., 132(15): 387 - 388. DOI: 10.1136/vr.132.15.387

VÁRADY, M., BJORN, H., NANSEN, P. (1996): In vitro characterization of anthelmintic susceptibility of field isolates of the pig nodular worm Oesophagostomum spp., susceptible or resistant to various anthelmintics. Int. J. Parasitol., 26(7): 733 - 740. DOI: 10.1016/00207519(96)00051-3

Várady, M., Papadopoulos, E., Dolinská, M., Königová, A. (2011): Anthelmintic resistance in parasites of small ruminants: sheep versus goats. Helminthologia, 48(3): 137 - 144. DOI: 10.2478/ s11687-011-0021-7

Zanzani, S.A., Gazzonis, A.L., DI Cerbo, A., Várady, M., Manfredi, M.T. (2014): Gastrointestinal nematodes of dairy goats, anthelmintic resistance and practices of parasite control in Northern Italy. BMC Vet. Res., 10: 114. DOI: 10.1186/1746-6148-10-114 